\title{
GÊNERO/RAÇA: TÓPICOS PARA UMA REFLEXÃO BIOÉTICA
}

Nádia T. Covolan*

\section{Resumo}

Em nosso país, as situações emergentes ocasionadas pelos avanços científicos e tecnológicos requerem reflexões éticas afinadas com a contemporaneidade, porém, a falta de universalidade no acesso das pessoas aos bens desse desenvolvimento é condição persistente, relacionada com desigualdades que mesclam fortemente gênero e raça e continuam a clamar por maior equidade. Nesse sentido, abordo nesta comunicação alguns tópicos sobre gênero e raça, para mostrar que tais assimetrias tem raízes profundas na nossa história e para defender a necessidade da vinculação dessas categorias na reflexão bioética que queira contemplar, realmente, a realidade brasileira

\section{INTRODUÇÃO}

Na década de setenta, a partir dos EUA, surge uma reflexão ética forte direcionada aos paradoxos colocados pelo desenvolvimento científico e tecnológico, a bioética, definida como

o estudo sistemático das dimensões morais - incluindo visão, decisão e normas morais - das ciências da vida e do cuidado da saúde, utilizando uma variedade de metodologias éticas num contexto multidisciplinar. ${ }^{1}$

* Mestre em Tecnologia pela UTFPR e doutora em Ciências Humanas pela Universidade Federal de Santa Catarina. Professora da Universidade Federal do Paraná. (nira1@terra.com.br)

1 REICH, W.T. Encyclopedia of Bioethics, 2 ed. New York: MacMillan, 1995, XXI. 
Trata-se de refletir sobre os novos rumos que a ciência e a tecnologia estão tomando, uma vez que seus efeitos, agora, atingem o âmago da matéria, 0 átomo e os genes, podendo transformar radicalmente a face da terra e 0 que se compreende como humanidade. Ora, nessas convivências estranhas e antagônicas, tais como trangênicos, clonagens, armas de destruição em massa, reprodução assistida e curas inusitadas, não podemos ignorar que a vida humana nunca foi tão longa, nem se obteve tanta possibilidade de qualidade de vida.

Nesse contexto, porém, estima-se que dois terços da população do planeta não tem acesso aos benefícios desse desenvolvimento, e nem sequer condições básicas de existência digna. Alimentando esta situação de iniqüidade no mundo, diz o epidemiologista Jaime Breill que há três fontes de igual importância, a saber: as condições de gênero, a econômica e a étnica:

A fonte primeira de toda iniqüidade foi a apropriação de poder, que teve três formas originais: a apropriação privada da riqueza que deu origem às classes sociais, a apropriação patriarcal de poder e a apropriação de poder por parte de grupos étnicos historicamente situados em vantagem estratégica².

Comentando as palavras desse autor, a médica antropóloga Maria Lúcia Silveira acrescenta que:

no cerne de uma compreensão integral de eqüidade deve estar o grau de acesso ao poder e a forma como este se distribui e se reproduz, de acordo com o desenvolvimento de relações históricas. A partir daí, propõe que para compreender a iniqüidade entre grupos humanos há que se penetrar nas determinações e explicações essenciais de como se distribui o poder entre classes, categorias etnonacionais e de gênero. ${ }^{3}$

2 Breilh, Jaime. Epidemiologia: economia, política e saúde. São Paulo: Editora Hucitec,1991, p. 20).

3 SILVEIRA, Maria Lúcia da. Gênero, saúde e iniqüidades: o caso das mulheres. Texto de palestra, CEFET-PR. 2004. 
Assim, a sociedade brasileira com seus contrastes apresenta o desafio de desenvolver uma bioética que valorize nossas características, dentre as quais se encontra a exclusão social da maioria da população, que possui uma interface cruel de gênero e raça.

Utilizar o termo raça é complexo, dado que a história das definições e classificações de pessoas, grupos, sociedades, vão desde a cor da pele a inúmeras outras características. No entanto, aqui entendo os termos raça e etnia, no sentido em que foi saudado quando de sua incorporação a um documento das Nações Unidas, como o produzido pelas mulheres negras de 16 países da América Latina para a Conferência de Beijing. Dessa forma, utilizo e compreendo que raça e etnia são termos políticos, cujo uso pode iniciar discussões sobre desigualdades, e que portanto devem ser contemplados e explicitados nas reflexões bioéticas.

Outrossim, em que pese as controvérsias sobre o uso ou não da categoria gênero, aqui a utilizo e compreendo como:

uma forma particular de posicionamento social dos corpos vividos em relação uns aos outros, dentro de instituições e processos históricos específicos que tem efeitos materiais na ação e reprodução de relações de poder e privilégio entre si. Sob essa ótica, o que significa dizer que indivíduos são "generizados" é que todos nós nos encontramos passivamente agrupados de acordo com essas relações estruturais, de maneiras muito impessoais para fundar identidades ${ }^{4}$

\section{PARA FALAR DE GÊNERO E RAÇA NA CIÊNCIA E NA SOCIEDADE}

Poderosas analogias ligaram raça e gênero, e ocuparam lugares estratégicos nas teorias científicas sobre a variação humana, nos séculos passados.

Nesse sentido, Nancy Stepan informa que, no século XIX, vastos estudos consideraram o gênero como análogo à raça, ou seja, cientistas

4 Young, Corpo vivido vs. Gênero: Reflexões sobre a estrutura social e subjetividade. Labrys, estudos feministas, número 3, janeiro/julho, 2003. 
usaram a diferença racial para explicar a diferença de gênero e vice-versa. Assim, as raças consideradas inferiores representavam o feminino da espécie humana, tal como as mulheres representavam a raça inferior do gênero humano. Através de analogias, a diversidade humana, a mulher, o homossexual, o criminoso, o pobre, foram considerados raças à parte, que deviam ser naturalmente submetidos e inferiorizados na hierarquia social. Assim, a autora assinala que metáforas e analogias dirigem sempre a atenção do cientista para alguns aspectos da realidade e não para outros e que, por sua vez, a metáfora gera informações que moldam outras metáforas e as sustentam; por exemplo, a semelhança dos negros com os símios, baseada na formação de sua mandíbula, foi sustentada durante décadas, enquanto que, a semelhança dos brancos com os símios baseada nos lábios finos foi ignorada. Importante é atentar para o fato que as metáforas na ciência podem tornar-se dogmáticas, porque são identificadas com a realidade e a objetividade. Dessa forma, as analogias que relacionam raça, classe e gênero, como foram desenvolvidas nas ciências biossociais do século XIX, tiveram conseqüências que perpetuaram desigualdades morais, econômicas e sociais. A partir do século XX, esta analogia sexo/raça foi descartada e mudanças políticas e sociais se vincularam a novas metáforas da similaridade e igualdade humana. ${ }^{5}$

Isso porém, não impediu que o nascimento da bioética, nos EUA, ocorresse baseado num fato racista, tal qual o caso Tuskegee; este, divulgado em 1972, revelou que desde a década de trinta na cidade do mesmo nome, quatrocentos negros foram deixados sem tratamento para sífilis, já havendo medicamentos para a mesma, afim de realização de uma pesquisa de saúde pública, para perceber a evolução natural da doença. Casos de racismo que se transformaram em discriminações de conseqüências iníquas, também freqüentes no Brasil, tem longa história.

\section{GÊNERO, RAÇA E SEUS DISCURSOS NO BRASIL}

Conforme a filósofa Sueli Carneiro, no Brasil, o discurso sobre identidade nacional esconde a dimensão gênero/raça. Nossa sociedade

5 STEPAN, Nancy Leys. Raça e Gênero: o papel da analogia na ciência. Tendências e Impasses. O feminismo como crítica da cultura. Rio de janeiro: Rocco, 1994, p. 90. 
elaborou exemplos que enaltecem o trabalho das negras, quando se referem às amas de leite ou a alma boa que cozinha e cuida da família branca. As imagens construídas em torno da mãe preta desempenharam papel estratégico nas diferentes visões da natureza da escravidão no Brasil. No entanto, as bases materiais que sustentaram a existência das mães pretas nunca foram reveladas, assim como a subjetividade das escravas foi ignorada, afirmada ou diluída, enquanto se centrava a atenção no desempenho das suas funções. ${ }^{6}$

Como conseqüiências do acima descrito, a raça associada ao gênero ainda interfere na determinação de desigualdades salariais em nosso país. Fontes oficiais afirmam que homens negros, em média, ganham menos do que homens e mulheres brancos, mas são as negras, historicamente, as mais discriminadas. ${ }^{7}$

Nesse sentido, voltando a Carneiro, a literatura nacional, desde a colonização, retratou a mulher negra como exótica, sensual, quase próxima da animalidade, considerada, portanto, irresistível ao homem branco, fraco demais perante sua natural provocação. Por outro lado, foi construída uma imagem da mulher branca como submissa a um marido brutalizado. Apesar da nova historiografia mostrar uma escravidão inconformada, assim como uma senhora branca muitas vezes mais despótica que seu marido, permaneceram estereótipos que tornam impossível uma análise de gênero desvinculada da questão racial. ${ }^{8}$

Após a abolição da escravatura em 1888, a população negra continuou discriminada, permanecendo até hoje muitas formas de violência. Nesse sentido, Antonio Dias Filho, em seus estudos sobre o turismo sexual na Bahia, nos informa da reconstrução das identidades raciais das trabalhadoras do sexo (13 a 16 anos), que pesquisou. As raças, explica, são criadas com base num espectro cromático que garante o Sex Marketing. Assim, mulheres negras ou cafuzas se identificam como morenas-jambo,

6 CARNEIRO, Sueli. Gênero e Raça. Gênero, Democracia e sociedade Brasileira. São Paulo: Ed. 34, 2002, p. 191.

7 Brasil. Ministério das Relações Exteriores. Relatório Geral sobre a Mulher na Sociedade Brasileira, 1995.

8 CARNEIRO, S. Op. Cit. 
para agradar turistas estrangeiros ricos sedentos de fantasias sexuais com as nativas exóticas das propagandas das agências de viagens. ${ }^{9}$

Somando-se à violência sexual estão as condições de trabalho, acesso à educação e especialmente, à saúde:

se, historicamente, as práticas genocidas - como a violência policial, o extermínio de crianças, a ausência de políticas sociais que assegurem o exercício dos direitos básicos de cidadania - tem sido objeto prioritário da ação política dos movimentos negros, os problemas colocados hoje pelos temas da saúde e de população nos situam num quadro talvez ainda mais alarmante quanto aos processos de genocídio do povo negro no Brasil. ${ }^{10}$

Nesse sentido, é exemplar o estudo de Estela Garcia de Pinto Cunha, em que informa que a mortalidade em menores de um ano no Brasil, teve diminuição significativa de suas taxas (33\%), nos últimos anos, porém,

quando se faz intervir a variável cor, constata-se que aqueles classificados como brancos conseguiram diminuir a mortalidade de menores de um ano em 43\%, enquanto os negros o fizeram em ritmo significativamente menos (25\%). As desigualdades raciais se acentuaram através do tempo: enquanto a diferença relativa entre os níveis de mortalidade de menores de um ano dos negros e brancos, segundo os dados do Censo de 1980, era de 25\%, este valor aumentou para $40 \% .^{11}$

Comentando o assunto, a médica Fátima de Oliveira assinala que filhos de mães negras são mais expostos aos riscos de adoecer e morrer devido a piores condições de trabalho e à falta de acesso à educação e assistência à saúde. Assim, pode afirmar que em nosso país a mortalidade

9 DIAS FILHO, Antônio. As mulatas que não estão no mapa. Cadernos Pagú, Raça e Gênero. PAGU - Núcleo de Estudos do Gênero/Unicamp, nº 6/7, 1996.

${ }^{10}$ CARNEIRO, S. Op. cit.

${ }^{11}$ CUNHA, ESTELA M.G.P. Diferenciais na Mortalidade de Menores de um ano segundo Raça: Novas constatações. www.abep.nepo.unicamp.br/docs/anais/PDF/1998/a195.pdf 
infantil e materna, indicadores da qualidade de vida de um povo, tem cor. Para esta autora, um novo contexto também se apresenta na redução da população negra, que é o ocasionado pela esterilização em massa, pela desconsideração de doenças étnicas/raciais e pela progressão da AIDS. ${ }^{12}$

\section{CONSIDERAÇÕES FINAIS}

Conforme Volnei Garrafa, a atual pauta bioética internacional está voltada tanto para as situações emergentes relacionadas com as novidades postas pelo avanço científico/tecnológico, quanto para as persistentes relativas a falta de universalidade de acesso das pessoas aos bens do desenvolvimento. ${ }^{13}$ Nesse contexto, os estudiosos da bioética Léo Pessini e Christian de Paul de Barchifontaine, tocam em fibras sensíveis da questão para a América Latina:

uma macrobioética precisa ser proposta como alternativa à tradição anglo-americana de uma microbioética (solução de casos clínicos). Na América-Latina, a bioética sumarizada num "bios" de alta tecnologia e num "ethos" individualista (privacidade, autonomia, consentimento informado), precisa ser complementada por um "bios" humanista e um "ethos" comunitário (solidariedade, equidade, o outro). ${ }^{14}$

Nesse contexto, quero assinalar que, em nosso país, se a bioética tem constatado, timidamente, a importância de abordar a questão econômica de nosso povo nos aspectos das situações emergentes/persistentes, tem sido tremendamente falha, para não dizer inexistente, quando se trata de vincular as categorias de análise gênero e raça às suas/estas reflexões. Vozes em defesa dessa vinculação têm sido enunciadas por raras feministas e/ou estudiosas (os) da bioética, porém nada se avizinha, ainda, no sentido

12 OLIVEIRA, Fátima. Mulher, saúde, recorte racial/étnico: uma articulação necessária. Mulheres Negras. Fille:/C: \Meus documentos \fátimaoliveria.htm. acessado em 21/19/2001.

${ }^{13}$ GARRAFA, V. Bioética e Ciência: Até onde avançar sem Agredit. Iniciação à Bioética.Brasília: Conselho Federal de Medicina, 1998, p. 100.

${ }^{14}$ PESSINI, L e BARCHIFONTAINE, C.Bioética: do Principialismo à busca de uma Perspectiva Latino-Americana. Iniciação à Bioética. Brasília: CFM, 1998, p. 95. 
de um programa de estudos vinculados a órgãos públicos ou à Academia, que possa tornar essas vozes audíveis.

Conforme Maria Guimarães e Sílvia Novaes, vulneráveis são pessoas que, por suas condições sociais, culturais, étnicas, políticas, econômicas, educacionais e de saúde, têm as diferenças estabelecidas entre elas e as sociedades, transformadas em desigualdade. Desigualdade e diferença são, portanto, duas categorias separadas pelo acesso ou não ao poder social. ${ }^{15}$

Nesse sentido, a alocação de recursos em saúde, tema bioético por excelência, diz respeito à grande maioria da população brasileira, que tem a sua vulnerabilidade aumentada dado a generização assimétrica da sociedade e conseqüentemente, da ciência/tecnologia que carrega a marca humana do que se pensa, se faz e se distribui. Dessa forma, são inspiradores os aportes de Londa Schiebinger, para iniciar uma reflexão em alguns pontos básicos: a) sobre como são feitas as escolhas do que queremos saber (e do que escolhemos não saber) no contexto de nossos recursos limitados; b) sobre quem se beneficia em termos de riqueza e bem-estar e quem não, a partir de um projeto de pesquisa cientifico específico; c) que interesses políticos e decisões de financiamento destacam certas porções da natureza que se tornam conhecidas, enquanto outras são negligenciadas; e, d) especialmente, ciência para quem? ${ }^{16}$

Dessa forma, a busca da eqüidade é uma forma de fazer com que as diferenças não se tornem injustiças e, nesse caminho, é imprescindível a incorporação das categorias gênero e raça às análises e reflexões de uma bioética que pretenda contemplar tanto nossa realidade.

15 GUIMARÃES, Maria e NOVAES, Sílvia. Autonomia Reduzida e Vulnerabilidade: Liberdade, Decisão e Desigualdade. Bioética, v. 7, n 1, Brasília: CFM, 1999, p. 21-24.

${ }^{16}$ REICH, W.T. Encyclopedia of Bioethics, 2 ed. New York: MacMillan, 1995, XXI. 